\title{
Hypoxia Inducible Factor-1 $\alpha$ in Astrocytes and/or Myeloid Cells Is Not Required for the Development of Autoimmune Demyelinating Disease ${ }^{1,2,3}$
}

\author{
Natacha Le Moan,, ${ }^{1}$ Kim M. Baeten, ${ }^{1}$ Victoria A. Rafalski, ${ }^{1}$ Jae Kyu Ryu, ${ }^{1}$ Pamela E. Rios Coronado, ${ }^{1}$ \\ Catherine Bedard, ${ }^{1}$ Catriona Syme, ${ }^{1}$ Dimitrios Davalos, ${ }^{1}$ and Katerina Akassoglou ${ }^{1,2}$
}

DOI:http://dx.doi.org/10.1523/ENEURO.0050-14.2015

${ }^{1}$ Gladstone Institute of Neurological Disease, University of California, San Francisco, San Francisco, CA 94158, USA,

${ }^{2}$ Department of Neurology, University of California, San Francisco, San Francisco, CA 94143, USA

\begin{abstract}
Hypoxia-like tissue alterations, characterized by the upregulation of hypoxia-inducible factor- $1 \alpha(\mathrm{HIF}-1 \alpha)$, have been described in the normal appearing white matter and pre-demyelinating lesions of multiple sclerosis (MS) patients. As $\mathrm{HIF}-1 \alpha$ regulates the transcription of a wide set of genes involved in neuroprotection and neuroinflammation, HIF- $1 \alpha$ expression may contribute to the pathogenesis of inflammatory demyelination. To test this hypothesis, we analyzed the effect of cell-specific genetic ablation or overexpression of HIF-1 $\alpha$ on the onset and progression of experimental autoimmune encephalomyelitis (EAE), a mouse model for MS. HIF-1 $\alpha$ was mainly expressed in astrocytes and microglia/macrophages in the mouse spinal cord at the peak of EAE. However, genetic ablation of HIF- $1 \alpha$ in astrocytes and/or myeloid cells did not ameliorate clinical symptoms. Furthermore, conditional knock-out of Von Hippel Lindau, a negative regulator of HIF- $1 \alpha$ stabilization, failed to exacerbate the clinical course of EAE. In accordance with clinical symptoms, genetic ablation or overexpression of HIF- $1 \alpha$ did not change the extent of spinal cord inflammation and demyelination. Overall, our data indicate that despite dramatic upregulation of HIF- $1 \alpha$ in astrocytes and myeloid cells in EAE, HIF-1 $\alpha$ expression in these two cell types is not required for the development of inflammatory demyelination. Despite numerous reports indicating HIF- $1 \alpha$ expression in glia, neurons, and inflammatory cells in the CNS of MS patients, the cell-specific contribution of HIF- $1 \alpha$ to disease pathogenesis remains unclear. Here we show that although HIF- $1 \alpha$ is dramatically upregulated in astrocytes and myeloid cells in EAE, cell-specific depletion of HIF- $1 \alpha$ in these two cell types surprisingly does not affect the development of neuroinflammatory disease. Together with two recently published studies showing a role for oligodendrocyte-specific HIF- $1 \alpha$ in myelination and T-cell-specific HIF- $1 \alpha$ in EAE, our results demonstrate a tightly regulated cellular specificity for HIF-1 $\alpha$ contribution in nervous system pathogenesis.
\end{abstract}

Key words: astrocytes; cre/loxP; EAE; HIF-1alpha; macrophages; neuroinflammation

\section{Significance Statement}

Despite numerous reports indicating HIF-1 $\alpha$ expression in glia, neurons, and inflammatory cells in the CNS of MS patients, the cell-specific contribution of HIF-1 $\alpha$ to disease pathogenesis remains unclear. Here we show that although HIF-1 $\alpha$ is dramatically upregulated in astrocytes and myeloid cells in EAE, cell-specific depletion of HIF-1 $\alpha$ in these two cell types surprisingly does not affect the development of neuroinflammatory disease. Together with two recently published studies showing a role for oligodendrocyte-specific $\mathrm{HIF}-1 \alpha$ in myelination and T-cell specific HIF- $1 \alpha$ in EAE, our results demonstrate a tightly regulated cellular specificity for HIF- $1 \alpha$ contribution in nervous system pathogenesis. 


\section{Introduction}

Multiple sclerosis (MS) is a chronic inflammatory demyelinating disease of the nervous system characterized by inflammation, gliosis, destruction of myelin sheaths, and axonal damage leading to permanent functional deficits (Brück and Stadelmann, 2005). Hypoxia-like tissue alterations, predominantly characterized by the accumulation of the hypoxia-inducible factor- $1 \alpha$ ( $\mathrm{HIF}-1 \alpha)$, occur at a very early stage in MS pathogenesis (Aboul-Enein et al., 2003; Graumann et al., 2003; Lassmann, 2003; Stadelmann et al., 2005; Marik et al., 2007; Zeis et al., 2008). Indeed, HIF- $1 \alpha$ is upregulated in pre-demyelinating lesions and normal appearing white matter (NAWM) of MS patients (Graumann et al., 2003; Zeis et al., 2008). Whereas $\mathrm{HIF}-1 \alpha$ expression is usually minimal or absent from active white matter lesions (Aboul-Enein et al., 2003; Marik et al., 2007), it is highly expressed in oligodendrocytes specifically in lesions with distal dying-back oligodendrogliopathy (Lassmann, 2003). Early hypoxic changes occurring within pre-demyelinating plaques are associated with microglia activation, perivascular accumulation of lymphocytes, blood-brain barrier (BBB) disruption and mild axonal injury (Marik et al., 2007). Determining the early hypoxic events leading to the formation of demyelinating lesions and their causative role in the pathology is crucial to better understand MS pathogenesis and discover novel targets and strategies for therapeutic intervention.

In the present study, we examined whether HIF-1 $\alpha$ expression regulates the onset and progression of inflammatory demyelination. HIF- $1 \alpha$ is a heterodimeric transcription factor that orchestrates the genetic response to hypoxic and inflammatory conditions by activating the transcription of a wide set of genes that regulate several biological processes, including cellular proliferation, sur-

Received October 27, 2014; accepted March 23, 2015; First published March 30, 2015 .

${ }^{1}$ The authors declare no competing financial interests.

${ }^{2}$ N.L.M. and K.A. designed research; N.L.M. performed the EAE and hypoxia experiments; N.L.M., K.M.B., J.K.R, V.A.R, and P.E.R.C. performed research and analyzed data; C.S. analyzed data; C.B. maintained the mouse colony; D.D. performed image analysis; N.L.M. and K.A. wrote paper with contribution from all authors.

${ }^{3}$ This work was supported by a National Multiple Sclerosis Society postdoctoral fellowship to N.L.M. and NIH/NINDS Grants R01NS051470 and R01NS052189 to K.A. V.A.R is an American Heart Association (AHA) postdoctoral fellow and D.D. holds Scientist Development Grant 13SDG17210051 from AHA. The J. David Gladstone Institutes received support from a National Center for Research Resources (Grant RR18928)

Acknowledgements: We thank the Mouse Pathology Core of the UCSF Helen Diller Family Comprehensive Cancer Center supported by CA082103 and Grisell Diaz-Ramirez at the Gladstone Institutes Bioinformatics Core for expert assistance; Belinda Cabriga and Matthew Helmrick for technical support; and Gary Howard for editorial support.

Correspondence should be addressed to Katerina Akassoglou, Gladstone Institute of Neurological Disease and Department of Neurology, University of California, San Francisco, 1650 Owens Street, San Francisco, CA 94158. E-mail: kakassoglou@gladstone.ucsf.edu.

DOI:http://dx.doi.org/10.1523/ENEURO.0050-14.2015

Copyright (C) 2015 Le Moan et al.

This is an open-access article distributed under the terms of the Creative Commons Attribution 4.0 International, which permits unrestricted use, distribution and reproduction in any medium provided that the original work is properly attributed. vival, angiogenesis, and glucose and iron metabolism (Sharp and Bernaudin, 2004; Majmundar et al., 2010). A central regulator of HIF- $1 \alpha$ turnover is Von Hippel Lindau (VHL), an ubiquitin ligase targeting $\mathrm{HIF}-1 \alpha$ for degradation (Kaelin, 2008). HIF-1 $\alpha$ function in the nervous system can be either protective by increasing the survival of neurons and oligodendrocytes (Baranova et al., 2007; Vangeison et al., 2008), or damaging by inducing BBB disruption (Argaw et al., 2006; Weidemann et al., 2009). The role of $\mathrm{HIF}-1 \alpha$ in inflammation has been examined in animal models of sepsis (Peyssonnaux et al., 2007; Thiel et al., 2007), rheumatoid arthritis and chronic cutaneous inflammation (Cramer et al., 2003) using conditional gene targeting approaches allowing tissue-specific deletion of HIF- $1 \alpha$ and VHL. Altogether these studies described that overexpression of $\mathrm{HIF}-1 \alpha$ results in hyperinflammatory responses and increased vascular permeability (Weidemann et al., 2009), whereas ablation of HIF- $1 \alpha$ decreases inflammation (Cramer et al., 2003; Peyssonnaux et al., 2007; Thiel et al., 2007). Although the role of HIF-1 $\alpha$ in peripheral inflammatory responses is well defined, whether glial-cell-specific expression of HIF- $1 \alpha$ plays a protective or damaging effect in inflammatory demyelination is unknown.

Here we show that similar to MS lesions, HIF- $1 \alpha$ is induced mainly in astrocytes and microglia/macrophages in white matter areas in experimental autoimmune encephalomyelitis (EAE), a mouse model for MS. Surprisingly, cell-specific genetic ablation of HIF- $1 \alpha$ in astrocytes and/or myeloid cells does not change disease onset or progression. Overall, we find that despite considerable upregulation of HIF- $1 \alpha$ in glia and monocytes during neuroinflammation, astrocyte-specific and/or myeloid-cellspecific expression of HIF- $1 \alpha$ does not affect the development of inflammatory demyelinating disease.

\section{Material and Methods}

Mice. Six-week-old female C57BL/6 mice were purchased from Charles River Laboratories. HIF-1 $\alpha^{\text {fl/fl }}$ C57BL/6 (Ryan et al., 2000), VHL ${ }^{\text {flffl }} \mathrm{C} ; 129 \mathrm{~S}$ (Haase et al., 2001), and HIF-1 $\alpha^{\text {luc }}$ FVB/NJ (Safran et al., 2006) mice were obtained from The Jackson Laboratory. $V H L^{f / f l}$ $\mathrm{C} ; 129 \mathrm{~S}$ and HIF-1 $\alpha^{\text {luc }} \mathrm{FVB} / \mathrm{NJ}$ mice were backcrossed at least six generations with pure C57BL/6 mice to perform EAE experiments. We then crossed $H I F-1 \alpha^{f l / f l}$ mice with mice expressing the cre recombinase driven by the lysozyme M promoter (lysM-Cre; Clausen et al., 1999) or the glial fibrillary acidic protein (GFAP) promoter (GFAP-Cre; Bajenaru et al., 2002) to generate cell-specific depletion of HIF- $1 \alpha$ in microglia/macrophages or astrocytes respectively. IysM-Cre mice were also crossed with $\mathrm{VHL}^{\text {fl/fl }}$ to generate cell-specific overexpression of HIF-1 $\alpha$ in the myeloid lineage. Mice were genotyped using the following

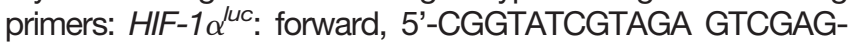
GCC-3'; reverse, 5'-GGTAGTGGTGGCATTAGCAGTAG-3' to detect the ODD-LuC CDNA and forward, 5'AAGGGAGCTGCAGTGGAGTA-3'; reverse, 5'-CCGAAAATC TGTGGGAAGTC-3' to detect the WT CDNA locus; HIF-1 $\alpha^{\text {fl/ff: }}$ forward, 5'-GTTGGGGCA GTACTGGAAAG-3'; reverse, 5'TGCTCATCAGTTGCCACTT-3'; VHL ${ }^{f l / f l}$ : forward, 5'- 
CAGCTTGCGAATCCGAGGGAC-3'; reverse, 5'CCTTCTGTCTTGGCCTCCTGAG-3'; GFAP-Cre: forward, 5'ACTCCTTCATAAAGCCCTCGCATCCC-3'; reverse, 5'ATCACT CGTTGCATCGACCG-3'; lysozyme M-Cre: forward, 5'-CTTGGGCTGCCAGAATTTCTC-3'; reverse, 5'CCCAGAAATGCCAGATTACG-3' and reverse, 5'TTACAGTCGGCCAGGCTG AC-3' as internal control. All animal procedures are performed according to the regulation of University of California, San Francisco's animal care committee.

$E A E$ induction and clinical assessment. EAE was induced in 6-wk-old female mice in the C57BL/6 background by subcutaneous injection of $50 \mu \mathrm{g} \mathrm{MOG}{ }_{35-55}$ (myelin oligodendrocyte glycoprotein; CPC Scientific) in complete Freund's adjuvant (CFA) (Sigma-Aldrich) supplemented with $200 \mathrm{ng}$ of heat-inactivated mycobacterium tuberculosis H37Ra (Difco Laboratories) as previously described (Adams et al., 2007). Control mice were injected only with CFA, as indicated. Mice were injected intravenously with 200 ng pertussis toxin (PTX; Sigma-Aldrich) on days 0 and 2 of the immunization. Mice were scored daily as follows: 0 , no symptoms; 1 , loss of tail tone; 2 , ataxia; 3 , hindlimb paralysis; 4 , hindlimb and forelimb paralysis; and 5, moribund.

Ex vivo luciferase assay. Proteins from mouse spinal cords were extracted on ice with a homogenizer in the Passive Lysis Buffer (Promega) supplemented with Protease and Phosphatase inhibitor cocktail set (Calbiochem). After a centrifugation at $13,000 \times g$ for $20 \mathrm{~min}$ at $4{ }^{\circ} \mathrm{C}, 20 \mu \mathrm{L}$ of the resulting supernatant was mixed with $50 \mu \mathrm{L}$ of luciferase substrate (Luciferin, Promega) and the luminescence was measured on the Monolight 2010 luminometer (BD Biosciences). Relative light units (RLUs) for luciferase were normalized to the optical density (OD) at $600 \mathrm{~nm}$ of respective spinal cord lysates.

Induction of hypoxia. Hypoxia was induced as previously described (Le Moan et al., 2011). Briefly, adult WT mice were exposed to $8 \% \mathrm{O}_{2}$ for $6 \mathrm{~h}$ in an $\mathrm{O}_{2}$ chamber controlled by the ProOx P110 and $\mathrm{ProCO}_{2} \mathrm{P} 120$ systems (BioSpherix). Control mice were kept in the same room under ambient $\mathrm{O}_{2}$. Mice were killed and brains lysed on ice in lysis buffer (100 mm NaCl, $1 \mathrm{~mm}$ EDTA, and $20 \mathrm{~mm}$ Tris- $\mathrm{HCl}, \mathrm{pH} 7.4,10 \%$ glycerol) containing $0.5 \%$ Tween 20 and supplemented with protease and phosphatase inhibitor cocktail (Calbiochem). Protein extracts were then analyzed for HIF- $1 \alpha$ levels by Western blot.

Western blotting. Proteins from mouse tissues were extracted on ice with a homogenizer in a lysis buffer containing the following: $50 \mathrm{~mm}$ Tris- $\mathrm{HCl}, \mathrm{pH} 7.5,150 \mathrm{~mm}$ $\mathrm{NaCl}, 1 \% \mathrm{NP}-40,5 \mathrm{~mm}$ EGTA, $5 \mathrm{~mm}$ EDTA, and $20 \mathrm{~mm}$ $\mathrm{NaF}$, and supplemented with Protease and Phosphatase inhibitor cocktail set (Calbiochem). The tissue lysates were cleared by a centrifugation at $13,000 \times g$ for $20 \mathrm{~min}$ at $4{ }^{\circ} \mathrm{C}$. Protein concentration of the resulting supernatant was determined by the Bio-Rad protein assay (Bio-Rad). Equal amounts of tissue extracts $(60 \mu \mathrm{g})$ dissolved in Laemmli Buffer were separated by $8-16 \%$ SDS-PAGE and Western blotting was performed as previously described (Le Moan et al., 2011). The membranes were probed with the rabbit polyclonal anti-mouse HIF- $1 \alpha$ an- tibody (1:500, Novus Biological) and the mouse monoclonal anti- $\beta$-actin antibody (1:10,000, Sigma-Aldrich) and developed by chemiluminescence (ECL Plus, GE Healthcare).

Quantitative real-time PCR. Total RNA was extracted from spinal cords using the RNeasy kit (Qiagen) according to the manufacturer instructions. Reverse transcription and real-time PCR (RT-PCR) on a StepOnePlus Real-Time PCR System (Applied Biosystems) were performed as previously described (Le Moan et al., 2011) in a $25 \mu \mathrm{L}$ reaction using $2 \mu \mathrm{L}$ of cDNA template, $12.5 \mu \mathrm{L}$ of SYBR Green PCR Master Mix (Applied Biosystems), and $1 \mu \mathrm{L}$ of the following sense and antisense primers: inducible nitric oxide synthase (iNOS): forward, 5'-GGCAAACCCAAGGTCTACGTT3'; reverse, 5'-TCGCTCAAG TTCAGCTTGGT-3'; erythropoietin (EPO): forward, 5'-CATCTGCGACAGTCGAGTTCTG-3'; reverse, 5'-CACAACCCATCGTGACATTTT C-3', HIF-1 $\alpha$ : forward, 5'-ACCTTCATCGGAAACTCC AAA G-3'; reverse, 5'CTGTTAGGCTGGGAAAAGTTA GG-3'; L7: forward, 5'GAAGCT CATCTATGAGAAGGC-3'; reverse, 5'AAGACGAAGGAGCTGCAGAAC-3'. Thermocycling conditions were the following: initial step of $10 \mathrm{~min}$ at $95^{\circ} \mathrm{C}$, and then 40 cycles of $15 \mathrm{~s}$ denaturation at $95^{\circ} \mathrm{C}$ and $1 \mathrm{~min}$ annealing and extension at $60^{\circ} \mathrm{C}$. Results were analyzed with the StepOne Software v2.0 using the comparative CT method. Transcripts of gene of interest were normalized against the transcripts of the mouse ribosomal protein $L 7$, used as a housekeeping gene, and were presented as fold-change versus the L7 transcript content. Each RT-PCR was performed in triplicate and repeated in three different animals.

Immunohistochemistry. Mice were anesthetized and transcardially perfused with ice-cold PBS solution containing zinc $(3.9 \mathrm{mg} / \mathrm{ml})$ as previously described (Sun et al., 2008). Brains and spinal cords were dissected and frozen in OCT-compound. Sections of $10 \mu \mathrm{m}$ thickness were fixed overnight in a zinc fixative solution $(0.1 \mathrm{M}$ Tris, $\mathrm{pH} 7.4,0.05 \%$ calcium acetate, $0.5 \%$ zinc acetate, and $0.5 \%$ zinc chloride) and immunostained overnight at $4{ }^{\circ} \mathrm{C}$ with a rabbit polyclonal anti-mouse $\mathrm{HIF}-1 \alpha$ antibody (1/ 500 , Novus Biological). For light microscopy immunostaining, HIF- $1 \alpha$ signal was developed by the peroxidase substrate 3-amino-9-ethylcarbazole (Sigma-Aldrich). The signal specificity was determined by omission of the primary antibody and by pre-adsorption of the primary antibody with the NB100-449 blocking peptide (Novus Biological). Double-immunofluorescence staining was performed with antibodies against GFAP (rat anti-GFAP: 1:1000, Zymed Laboratories) and Isolectin B4 (biotin IsoB4: 1/300, Sigma-Aldrich). Images were acquired with an Axioplan II epifluorescence microscope (Carl Zeiss) equipped with dry Plan-Neofluar objectives $(10 \times 0.3 \mathrm{NA}$, $20 \times 0.5 \mathrm{NA}$, or $40 \times 0.75 \mathrm{NA}$ ) using an Axiocam HRc CCD camera and the Axiovision image analysis software.

Histopathology. Histopathologic analysis and quantitation of inflammation and demyelination in mouse tissue were performed on paraffin sections as previously described (Adams et al., 2007). Sections were stained with hematoxylin/eosin and luxol fast blue/periodic acid-Schiff stain (LFB/PAS). Demyelinated areas were quantified on LFB/PAS stained sections using Axiovision software. Ar- 


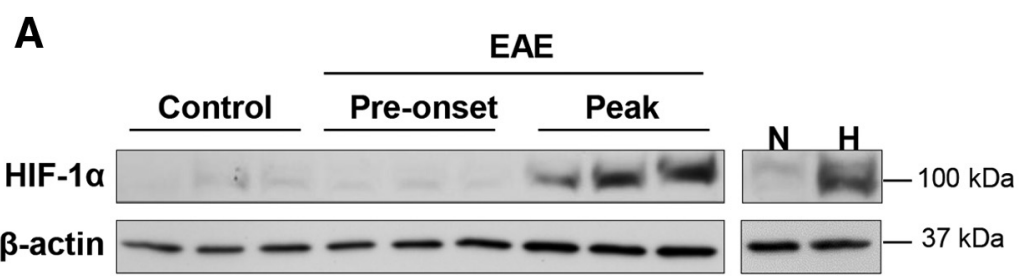

B

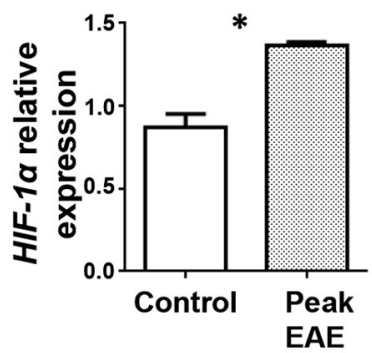

C

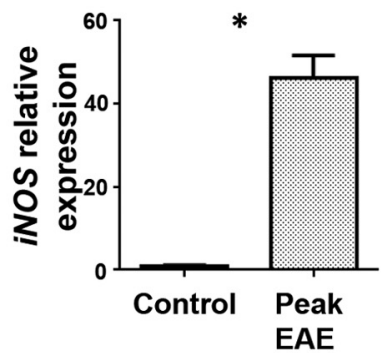

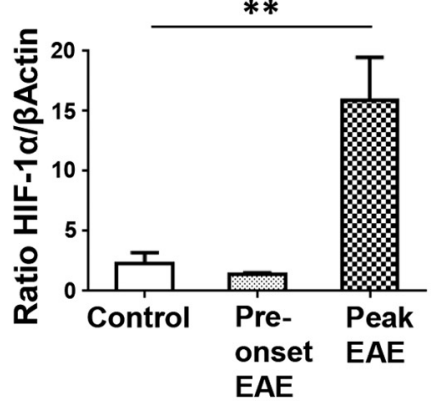

EAE

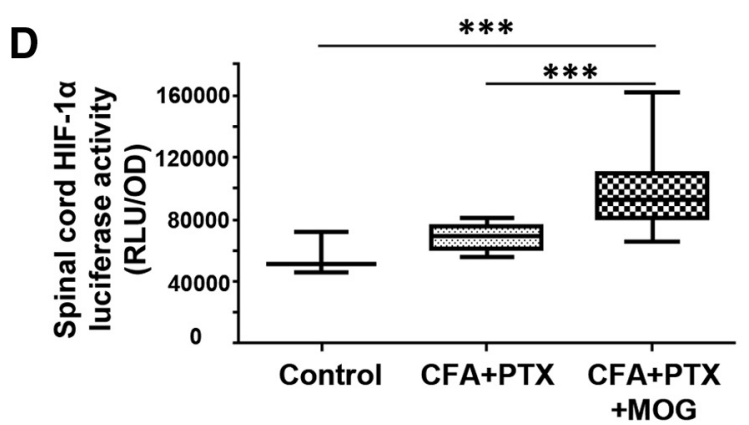

Figure 1 Stabilization and transcriptional activation of HIF- $1 \alpha$ in the spinal cord of EAE mice. $\boldsymbol{A}$, Western blot for HIF- $1 \alpha$ in spinal cords of control $(n=3)$, pre-onset EAE, day 7 postimmunization (p.i.; $n=3)$ and peak EAE, day 16 p.i. $(n=3)$ mice. Normoxic $\left(21 \% \mathrm{O}_{2}\right)$ and hypoxic $\left(10 \% \mathrm{O}_{2}\right)$ brain extracts were loaded with spinal cord extracts of EAE mice to demonstrate HIF-1 $\alpha$ protein stabilization. $\beta$-Actin-loading controls were performed on the same membrane. N, Normoxia; $\mathrm{H}$, hypoxia. ANOVA: $p=0.002^{a}$. Peak EAE had a higher ratio of HIF-1 $\alpha / \beta$-actin than control $\left(p=0.006^{a}\right)$ or pre-onset EAE mice $\left(p=0.003^{a}\right)$. B, Quantitative real-time PCR analysis of HIF-1 $\alpha$ expression in spinal cords of control $(n=3)$ and peak EAE $(n=3)$ mice, $p=0.01^{b}$. C, Quantitative real-time PCR analysis of HIF- $1 \alpha$ target genes iNOS and EPO in spinal cords of control $(n=3)$ and peak EAE $(n=3)$ mice, $p=0.03^{c}$ and $p=0.04^{d}$. $\boldsymbol{D}$, Quantitative analysis of photon emission in spinal cord of $H I F-1 \alpha^{l u c}$ control $(n=3)$ and peak EAE mice with MOG/CFA/PTX $(n=12)$ or CFA/PTX $(n=15)$. ANOVA: $p=0.00004^{e}$. MOG/CFA/PTX had greater bioluminescence than both CFA/PTX $\left(p=0.0005^{e}\right)$ and control mice $\left(p=0.0005^{e}\right)$. HIF-1 $\alpha^{l u c}$ mice were killed and spinal cord tissues were excised to extract proteins. The bioluminescence signal was quantified ex vivo by the luciferase assay and expressed as RLUs per OD of proteins at $600 \mathrm{~nm}$. Data are presented as mean \pm SEM; $* p<0.05, * * p<0.01, * * * p<0.001$ by Holm's test in $\boldsymbol{B}$ and $\boldsymbol{C}$, and one-way ANOVA followed by Tukey multiple comparisons in $\boldsymbol{A}$ and $\boldsymbol{D}$. Superscript letters refer to the statistical results in Tables 1, 2, and Results.

eas of demyelination were manually outlined by an observer blinded to the genotype, and measured using Axiovision software. For each mouse, the sum of the demyelinated areas was divided by the number of coronal sections throughout the cord that were quantified (on average 8 per cord). Inflammation was assessed by immunohistochemistry following antigen retrieval in boiled target retrieval solution (Dako) using an antibody against CD3 (rabbit anti-CD3, 1/500; Abcam) and a secondary anti rabbit-cy3 (1/300, JAX). Anti-CD3+ cells were counted on coronal sections throughout the cord (typically 8 per mouse) within regions of interest. Regions-ofinterest consisted of 20 boxes of $100 \mu \mathrm{m} \times 100 \mu \mathrm{m}$ per cross section, placed in areas of parenchymal and meningeal inflammation. To detect macrophage infiltration we used rat anti-mouse Mac-2 (1:200, CEDARLANE) followed by a secondary anti rat-FITC $(1: 300$, JAX). Images were acquired by a Keyence Biorevo BZ-9000E and measurement of Mac-2+ area was performed using ImageJ. To detect iNOS-expressing astrocytes, we performed double-immunofluorescence staining with antibodies against iNOS (1:100, Abcam) and GFAP (1:1000, Zymed Laboratories). Images were acquired with an Axioplan II epifluorescence microscope (Carl Zeiss) and labeled cells were counted in the central area of spinal cord coronal sections within a region of interest (box of $200 \times 280 \mu \mathrm{m}$, 
six different rostrocaudal sections per animal). Quantification was performed by observers blinded to the genotypes of the mice.

Statistical analyses. Differences between experimental conditions were analyzed with ANOVAs and $t$ tests, and $p$ values were corrected for multiple comparisons using the method of Holm or Tukey's Honest Significant Difference. When normality and homoscedasticity assumptions were violated, data were transformed using a natural logarithmic transformation. For daily scoring of clinical score data, we fit a linear mixed-effects model (Laird and Ware, 1982; Lee et al., 2003) using the Ime4 package (Bates et al., 2013) in R (R Core Team, 2013). We used the fitted model to obtain estimates of the mean day of onset and the mean of the maximum clinical score for each genotype group. We performed a Fisher's exact test to determine whether there is a significant relationship between genotype and mice that achieve score 3 or higher during the experiment (percentage paralysis). Power and sample size analyses were performed with SAS 9.3. Data are shown as mean \pm SEM; $p<0.05$ was considered significant. Single comparisons to control were made using an unpaired $t$ test.

\section{Results}

HIF-1 $\alpha$ stabilization is increased in the mouse spinal cord at the peak of EAE

To determine the temporal regulation of HIF- $1 \alpha$ in neuroinflammatory disease, we compared $\mathrm{HIF}-1 \alpha$ expression in spinal cord extracts from EAE mice at the onset (day 7) and peak of disease (day 16) with healthy control mice (nonimmunized; Fig. 1A). HIF-1 $\alpha$ protein levels at the peak of EAE were $\sim 7$-fold higher compared with control (Fig. 1A). HIF-1 $\alpha$ was not detected in control mice or at the onset of EAE (Fig. 1A). Protein extracts from normoxic and hypoxic brains were used as a positive control of HIF- $1 \alpha$ accumulation (Fig. 1A). HIF-1 $\alpha$ RNA levels were $\sim 1.5$-fold higher at the peak of EAE (Fig. 1B), suggesting that $\mathrm{HIF}-1 \alpha$ expression is mainly regulated at the protein rather than the transcriptional level. In accordance, RNA expression analysis of $\mathrm{HIF}-1 \alpha$ target genes iNOS and EPO showed significant increase at the peak of EAE (Fig. 1C). Furthermore, we induced EAE in $\mathrm{HIF}-1 \alpha$ genetic reporter mice $\left(H I F-1 \alpha^{\prime u c}\right)$, which express the luciferase gene fused to the oxygen-sensing domain of HIF- $1 \alpha$ and used ex vivo bioluminescence assay as a sensitive and accurate strategy to quantify HIF- $1 \alpha$ accumulation in spinal cord extracts. Consistent with our biochemical results, the luciferase signal was significantly increased in $\mathrm{MOG}_{35-55^{-}}$ immunized mice at the EAE peak compared with control (Fig. 1D). Because exposure to bacterial pathogens, such as PTX, may increase HIF- $1 \alpha$ accumulation (Zinkernagel et al., 2007), we analyzed whether HIF-1 $\alpha$ is upregulated in the absence of the $\mathrm{MOG}_{35-55}$ peptide. Immunization of $H I F-1 \alpha^{\text {luc }}$ mice with only CFA and PTX did not increase luciferase signal (Fig. 1D), indicating that HIF- $1 \alpha$ is specifically upregulated in response to $\mathrm{MOG}_{35-55}$-induced EAE.
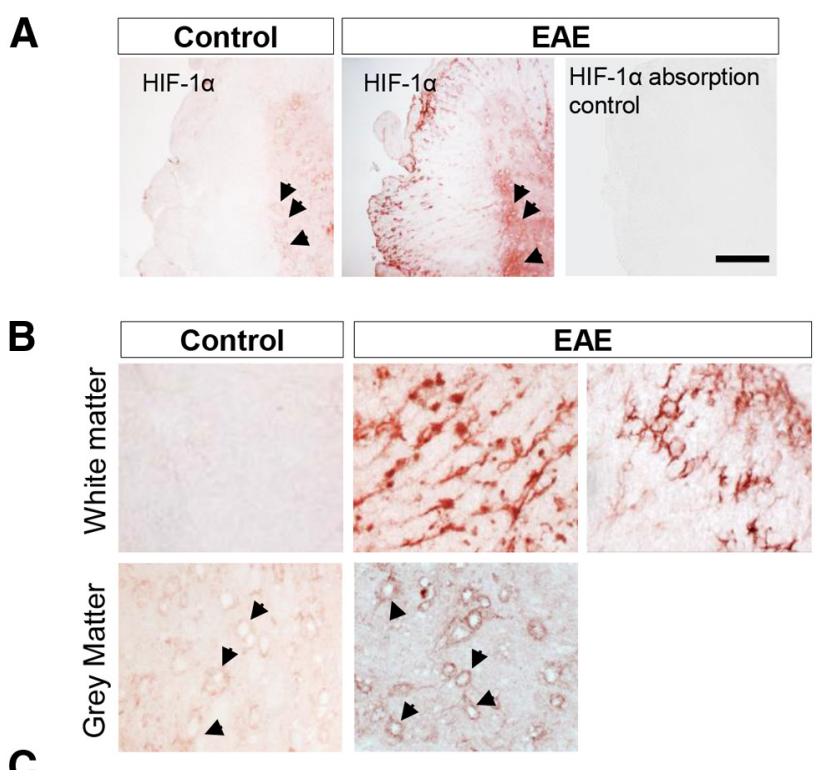

C
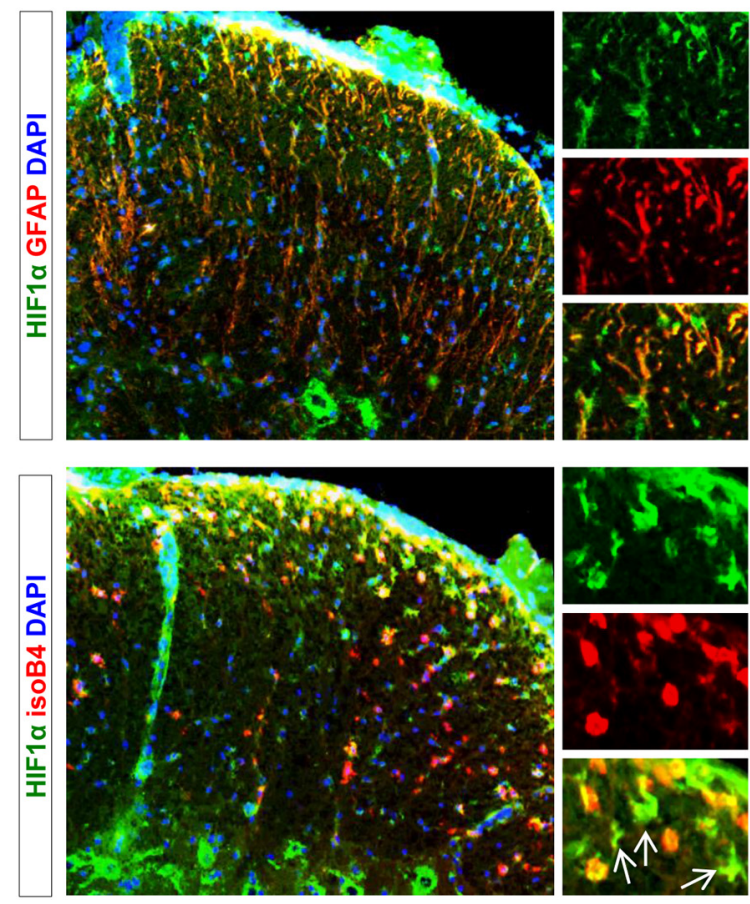

Figure $2 \mathrm{HIF}-1 \alpha$ is expressed in astrocytes and microglia/macrophages in the spinal cord of EAE mice. $\boldsymbol{A}$, Immunohistochemical staining for HIF- $1 \alpha$ in spinal cord sections from healthy mice and at peak EAE, $17 \mathrm{~d}$ p.i. Absorption control after anti-HIF-1 $\alpha$ antibody incubation with HIF-1 $\alpha$ blocking peptide at peak EAE. Scale bar, $300 \mu \mathrm{m}$. Arrows indicate neuronal cells. B, Highermagnification of HIF-1 $\alpha$ immunostaining in the grey and white matter of the spinal cord of healthy and EAE mice. Scale bar, 50 $\mu \mathrm{m}$. Arrows indicate neuronal cells. $\boldsymbol{C}$, Double-immunofluorescence with antibodies against HIF- $1 \alpha$ (green) and GFAP (top) or isoB4 (bottom) (red) of spinal cord sections of EAE mice $17 \mathrm{~d}$ after immunization. Scale bar, $50 \mu \mathrm{m}$. Arrows indicate HIF$1 \alpha^{+}$isoB4- cells with astrocyte-like morphology (green). 
A

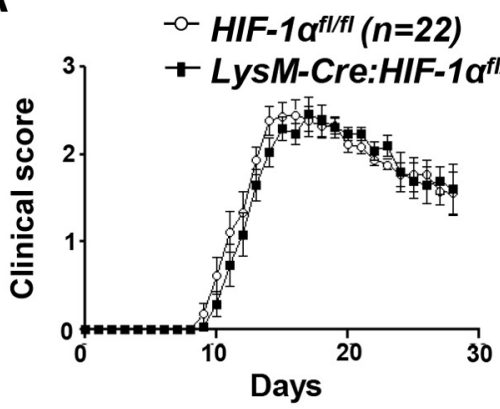

B

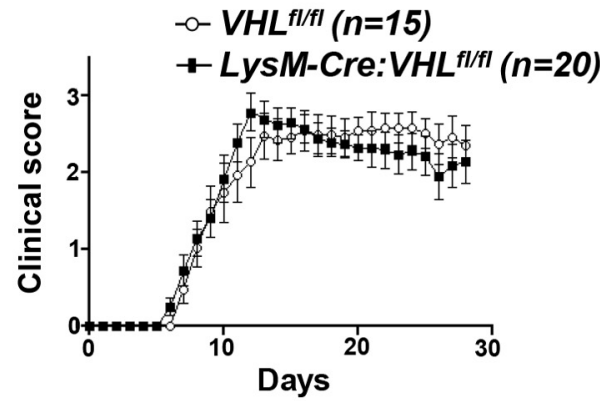

C
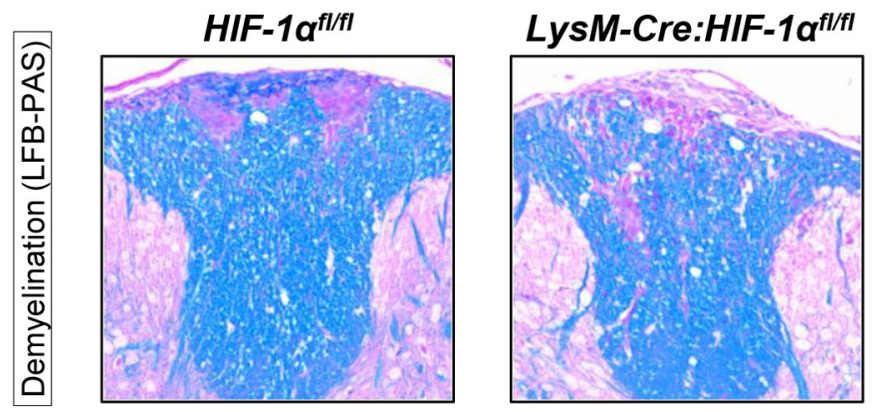

D
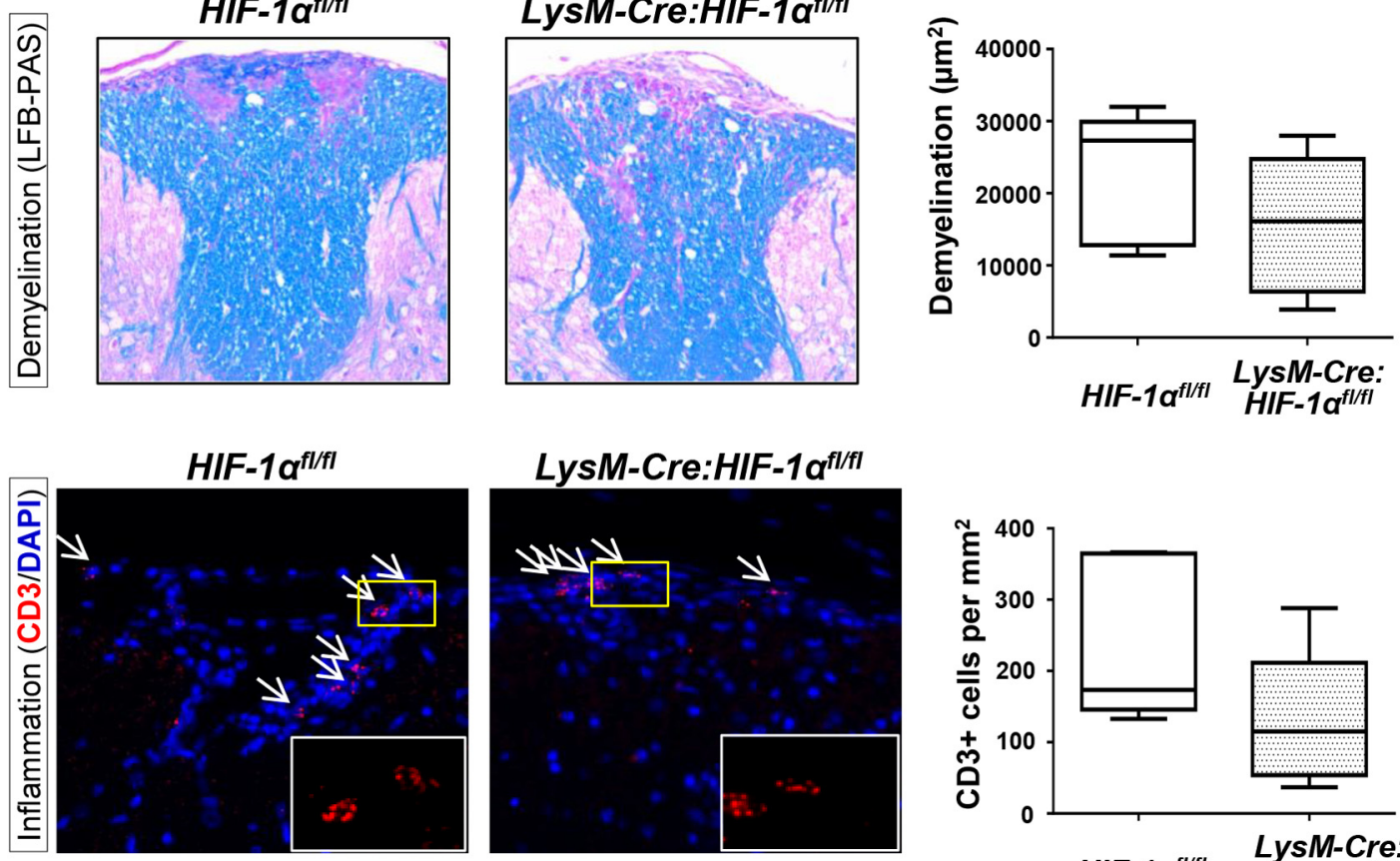

E

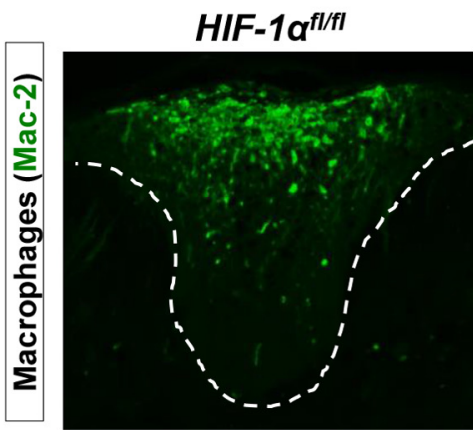

\section{LysM-Cre:HIF-1 $\alpha^{\text {fl/fI }}$}
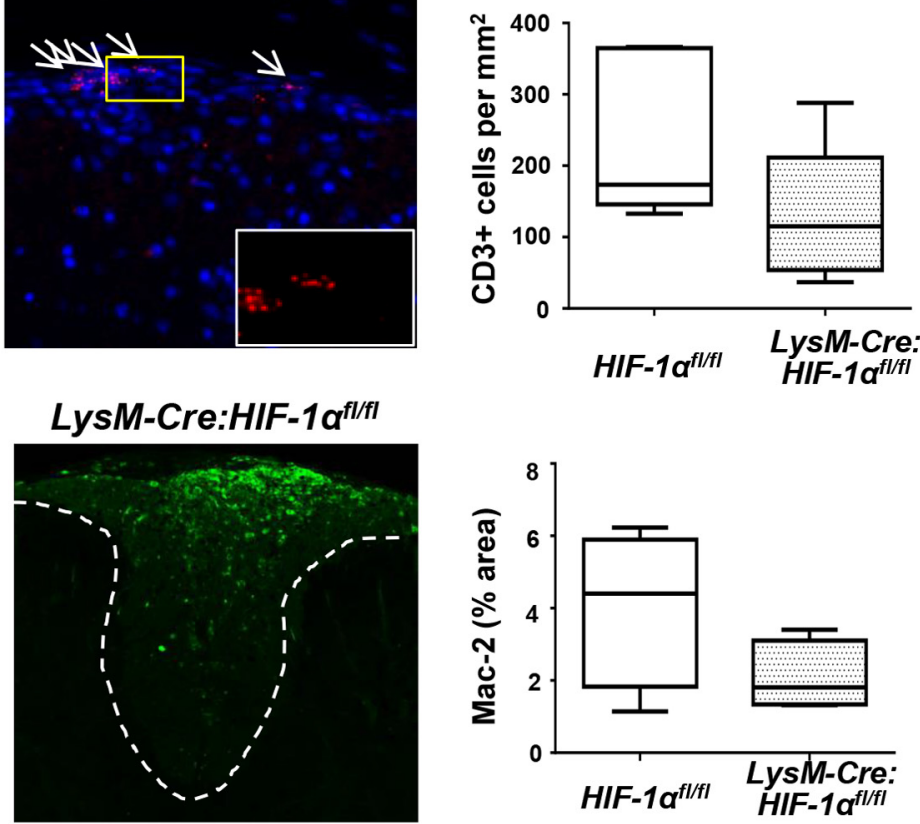

Figure 3 Genetic depletion or overexpression of HIF-1 $\alpha$ in myeloid cells does not affect the clinical course of EAE, demyelination, and inflammatory infiltrates. A, Clinical scores of mice genetically depleted for HIF-1 $\alpha$ in myeloid cells $l y s M-C r e: H I F-1 \alpha^{f l / f l}(n=17)$ and control mice HIF-1 $\alpha^{f l f f l}(n=22)$. B. Clinical scores of mice overexpressing HIF-1 $\alpha$ in microglia/macrophages $/ y s M C r e: V H L^{f l f l}(n=20)$ and control mice $V H L^{f / f l}(n=15)$. $\boldsymbol{A}$ and $\boldsymbol{B}$, For each genotype, day of onset, maximum clinical score, and percentage of mice developing signs of paralysis (score $\geq 3$ ) were calculated using mixed linear effects models, and the results are presented in Table 1. Data are presented as mean \pm SEM. C, LFB/PAS staining shows demyelination in $H I F-1 \alpha^{f l / f l}(n=5)$ and lysM-Cre:HIF-1 $\alpha^{f l / f l}(n=5)$. Data are presented as mean \pm SEM. Statistical analysis was performed using the unpaired $t$ test $\left(p=0.28^{\prime}\right)$. $D$, Immunohistochemistry for CD3 shows no significant differences in inflammation between $H I F-1 \alpha^{f l / f l}(n=5)$ and lysM-Cre:HIF-1 $\alpha^{\text {fl/fl }}(n=5)$. Data are expressed as number of CD3 + cells $/ \mathrm{mm}^{2}$ per mouse and presented as mean \pm SEM. Statistical analysis was performed using the unpaired $t$ test $\left(p=0.14^{\mathrm{m}}\right)$. E, Immunohistochemistry for Mac-2 shows no significant differences in inflammation between HIF-1 $\alpha^{\text {fl/fl }}$ $(n=4)$ and lysM-Cre:HIF-1 $\alpha^{\text {fl/fl }}(n=4)$. Data are expressed as percentage of Mac-2 + area per mouse and presented as mean \pm SEM. Statistical analysis was performed using unpaired $t$ test $\left(p=0.153^{n}\right)$. Superscript letters refer to the statistical results in Tables 1 , 2 , and Results. 
Table 1 Quantification of day of onset, clinical score, and paralysis in EAE experiments

\begin{tabular}{|c|c|c|c|c|c|c|c|c|}
\hline Experiment & Genotype & Mice, $n$ & $\begin{array}{l}\text { Day of } \\
\text { onset }(95 \% \mathrm{Cl})\end{array}$ & $p$ & $\begin{array}{l}\text { Maximum } \\
\text { clinical } \\
\text { score }(95 \% \mathrm{Cl})\end{array}$ & $p$ & Paralysis, \% & $p$ \\
\hline \multirow[t]{2}{*}{1} & lysM-Cre:HIF-1 $\alpha^{f \mid / f l}$ & 17 & $11.7(11.0-12.5)$ & $0.77^{f}$ & $2.71(2.43-2.98)$ & $0.77^{9}$ & 23.5 & $0.73^{h}$ \\
\hline & $H I F-1 \alpha^{f l / f l}$ & 22 & $11.4(11.0-12.0)$ & & $2.79(2.54-3.02)$ & & 31.8 & \\
\hline \multirow[t]{2}{*}{2} & lysM-Cre:VHL ${ }^{f l / f l}$ & 20 & $7.95(7.0-9.5)$ & $0.90^{i}$ & $2.95(2.32-3.52)$ & $0.90^{j}$ & 50 & $0.99^{k}$ \\
\hline & $V H L^{f l / f l}$ & 15 & $8.56(7.0-10.0)$ & & $2.82(2.15-3.47)$ & & 46.7 & \\
\hline \multirow[t]{2}{*}{3} & GFAP-Cre:HIF-1 $\alpha^{f l / f l}$ & 24 & $11.40(11.0-12.0)$ & $0.99^{s}$ & $2.81(2.43-3.17)$ & $0.99^{t}$ & 62.5 & $0.78^{u}$ \\
\hline & $H I F-1 \alpha^{f l / f l}$ & 27 & $11.29(11.0-12.0)$ & & $2.96(2.64-3.26)$ & & 55.6 & \\
\hline \multirow[t]{2}{*}{4} & GFAP-Cre:IysM-Cre:HIF-1 $\alpha^{f l / f l}$ & 16 & $11.44(10.5-12.0)$ & $0.65^{v}$ & $2.56(2.26-2.88)$ & $0.98^{w}$ & 12.5 & $0.19^{x}$ \\
\hline & $H I F-1 \alpha^{f l / f l}$ & 13 & $11.98(11.5-12.5)$ & & $2.57(2.27-2.86)$ & & 38.5 & \\
\hline
\end{tabular}

Experiment ${ }^{1}$ : EAE induction in lysM-Cre:HIF-1 $\alpha^{f l / f l}$ versus control mice $H I F-1 \alpha^{f l f l}$. Experiment ${ }^{2}$ : EAE induction in $/ y s M C r e: V H L^{f l / f l}$ versus control mice $V H L^{f l / f l}$ Experiment ${ }^{3}$ : EAE induction in GFAP-Cre:HIF-1 $\alpha^{f l / f l}$ versus control mice HIF-1 $\alpha^{f l / f l}$. Experiment ${ }^{4}$ : EAE induction in GFAP-Cre:lysM-Cre:HIF-1 $\alpha^{f l / f l}$ versus control mice HIF-1 $\alpha^{f l / f l}$. Day of onset defined as the first day that the score is $\geq 0.5$. A linear mixed-effects model was used to estimate means and $95 \%$ confidence interval $(\mathrm{Cl})$ for both day of onset and maximum clinical score for each genotype group. A Fisher's exact test was used to determine whether there is a significant relationship between genotype and mice that achieve score 3 or higher during the experiment (percentage paralysis). Superscript letters refer to the statistical results in Figures 3A, 3B, 5A and 5B. Results, and Table 2.

\section{HIF-1 $\alpha$ is expressed in astrocytes and microglia/macrophages in the mouse spinal cord at the peak of EAE}

In MS lesions, HIF- $1 \alpha$ is mainly upregulated in astrocytes and oligodendrocytes in the NAWM (Graumann et al., 2003; Zeis et al., 2008), neurons, astrocytes, and oligodendrocytes in pre-demyelinating MS lesions (AboulEnein et al., 2003; Marik et al., 2007), and in oligodendrocytes in active lesions with dying-back oligodendrogliopathy (Lassmann, 2003). We thus examined the cell-type-specific expression of HIF-1 $\alpha$ in spinal cords of EAE mice. Similar to our previous biochemical observations, immunohistochemistry showed HIF-1 $\alpha$ accumulation in mouse spinal cords at the peak of EAE (Fig. 2A). As expected, preincubation of the HIF-1 $\alpha$ antibody with a blocking peptide abolished the staining (Fig. 2A), indicating that the signal detected is specific for HIF-1 $\alpha$. HIF-1 $\alpha$ staining showed a homogenous and widespread pattern of expression both in grey and white matter areas of spinal cord tissue of EAE mice (Fig. 2A). HIF-1 $\alpha$ was weakly expressed in neurons of the grey matter in healthy control mice (Fig. 2A). At EAE peak, HIF-1 $\alpha$ was increased in neurons of the grey matter and induced in the white matter (Fig. 2A). Higher-magnification images show prominent staining of HIF-1 $\alpha$ in different cell types in the white matter area of the spinal cord of EAE mice (Fig. 2B). To identify the cell types that express HIF-1 $\alpha$ in the white matter after EAE, we performed double-immunofluorescence staining of HIF-1 $\alpha$ with cell-specific markers. At the peak of EAE, HIF-1 $\alpha$ colocalized with the astrocyte marker GFAP and the microglia/macrophage marker IsoB4 (Fig. 2C), indicating that astrocytes and microglia/ macrophages are the two major cell types that express $\mathrm{HIF}-1 \alpha$ in myelinated areas in EAE.

\section{Genetic ablation or overexpression of HIF-1 $\alpha$ in astrocytes or the myeloid lineage does not change the clinical course of EAE or demyelination}

To determine whether $\mathrm{HIF}-1 \alpha$ regulates the onset and progression of inflammatory demyelination, we generated four different mouse strains with cell-specific genetic depletion or overexpression of $\mathrm{HIF}-1 \alpha$ in astrocytes and myeloid cells. We generated cell-specific depletions of HIF- $1 \alpha$ by crossing HIF-1 $\alpha^{\text {fl/fl }}$ mice with lysM-Cre and/or GFAP-Cre mice, which allows specific depletion of HIF- $1 \alpha$ in the myeloid lineage and astrocytes, respectively. IysM-Cre:HIF-1 $\alpha^{\text {fl/fl }}$ and GFAP-Cre:HIF-1 $\alpha^{f l / f l}$ mice have extensive loss of $\mathrm{HIF}-1 \alpha$ in targeted cells, have a normal life span, do not display any obvious phenotypes, and show no obvious neurologic defects (Cramer et al., 2003; Weidemann et al., 2009). To determine whether there is a synergistic effect between astrocyte and monocyte expressed HIF-1 $\alpha$, we also generated GFAP-cre: lysM-Cre:HIF-1 $\alpha^{\text {fl/fl }}$ double-conditional knock-out mice to achieve simultaneous HIF-1 $\alpha$ depletion in both cell types. In addition, we generated mice to examine the role of targeted overexpression of $\mathrm{HIF}-1 \alpha$ via conditional depletion of VHL. GFAP-Cre:VHL ${ }^{f / f l}$ mice exhibit severe locomotive defects, hydrocephalus, and increased lethality at 6 weeks (Weidemann et al., 2009) that precludes their analysis in EAE. Therefore, we only generated lysM-Cre: $V H L^{f l / f l}$ mice.

We induced EAE with the $\mathrm{MOG}_{35-55}$ peptide and analyzed clinical signs in the four different mouse strains. Genetic depletion or overexpression of HIF- $1 \alpha$ in monocytes did not change the severity of clinical symptoms of EAE (Fig. 3A,B). No differences were observed in day of onset, maximum clinical score, and percentage of paralysis in lysM-Cre:HIF-1 $\alpha^{f / f l}$, lysM-Cre:VHL ${ }^{f l / f l}$, and HIF-1 $\alpha^{f l / f l}$ mice (Fig. 3A,B; Table 1). Histopathological analysis at EAE peak showed no significant differences in the extent of demyelination, $\mathrm{T}$ cell, and macrophage infiltration between lysM-Cre:HIF-1 $\alpha^{f l / f l}$ and HIF-1 $\alpha^{f l / f l}$ littermate control mice (Fig. 3C-E).

Immunohistochemistry for $\mathrm{HIF}-1 \alpha$ revealed a remarkable decrease of HIF- $1 \alpha$ in GFAP-Cre:HIF- $1 \alpha^{f l / f l}$ mice, suggesting that astrocytes are a major source of $\mathrm{HIF}-1 \alpha$ in the white matter during EAE (Fig. 4A). We further characterized how cell-specific depletion of HIF-1 $\alpha$ in astrocytes affected the expression of iNOS, a HIF-1 $\alpha$-target gene. In control HIF-1 $\alpha^{f l / f l}$ mice, iNOS was mainly expressed by astrocytes at the peak of EAE (Fig. 4B). In accordance with reduced expression of HIF-1 $\alpha$ (Fig. 4A), the total number of iNOS-expressing cells was decreased in 
Table 2 Statistical table

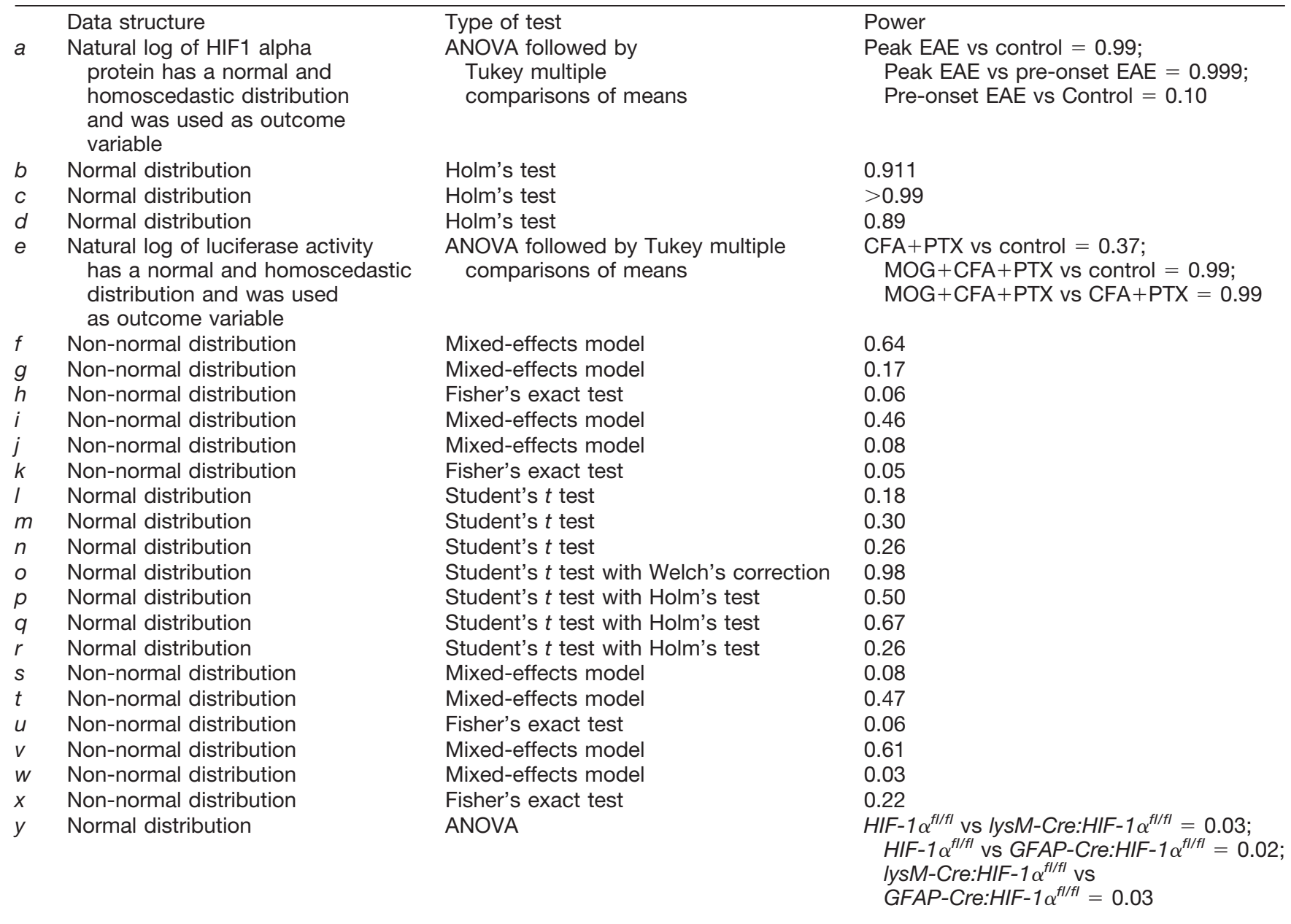

Superscript letters refer to the statistical tests in figures, Results, and Table 1.

GFAP-Cre:HIF-1 $\alpha^{\text {fl/fl }}$ mice compared with HIF-1 $\alpha^{\text {fl/fl }}$ control mice (Fig. 4C). At the peak of EAE in GFAP-Cre:HIF$1 \alpha^{f l / f l}$ mice, iNOS was significantly reduced in astrocytes (Fig. 4D,E), although no differences were observed in the total number of GFAP-expressing astrocytes (Fig. 4F). Overall, these results suggest that astrocyte expression of HIF- $1 \alpha$ and its downstream gene target iNOS are reduced in GFAP-Cre:HIF-1 $\alpha^{f / f f}$ mice. Despite the effect of HIF-a genetic depletion on astrocytic iNOS, no changes were observed in the severity of clinical symptoms of EAE (Fig. $5 A$; Table 1). Indeed, clinical signs, day of onset, maximum clinical score, and percentage of paralysis were also similar in GFAP-cre:IysM-Cre:HIF-1 $\alpha^{f l / f l}$ and HIF-1 $\alpha^{f \mid / f l}$ mice (Fig. 5B; Table 1), suggesting that depletion of HIF- $1 \alpha$ in both astrocytes and monocytes does not affect neuroinflammatory disease. Although GFAP-cre:lysMCre:HIF- $1 \alpha^{\text {fl/fl }}$ mice showed decreased percentage of paralysis, the effect was not significant (Table 1). HIF-1 $\alpha$ depletion in oligodendrocytes is involved in white matter angiogenesis (Yuen et al., 2014). However, mice with astrocyte or myeloid-specific deletion of HIF- $1 \alpha$ had no significant differences in vascular density after EAE (Fig. 5C). Overall, these results suggest that astrocyte and/or myeloid depletion of HIF- $1 \alpha$ is not essential for the development of EAE.

\section{Discussion}

In this study, we described that HIF- $1 \alpha$ expression is induced in astrocytes and microglia/macrophages in the spinal cord of EAE mice at the peak of the disease. In accordance, transcription of $\mathrm{HIF}-1 \alpha$ target genes iNOS and $E P O$, involved in neuronal damage and protection, is increased. Unexpectedly, we found that genetic depletion of HIF- $1 \alpha$ in astrocytes and cells of the myeloid lineage does not affect the development of neuroinflammatory disease. Accordingly, the extent of spinal cord inflammation and demyelination was similar between conditional knock-out and control mice. Together with two recently published studies showing a role for oligodendrocytespecific HIF-1 $\alpha$ in myelination (Yuen et al., 2014) and T-cell-specific HIF-1 $\alpha$ in EAE (Dang et al., 2011), our results demonstrate a tightly regulated cellular specificity for HIF- $1 \alpha$ contribution in nervous system pathogenesis.

Genetic manipulation of HIF- $1 \alpha$ in classical animal models of inflammation and neurodegeneration, including sepsis (Peyssonnaux et al., 2007; Thiel et al., 2007), rheu- 

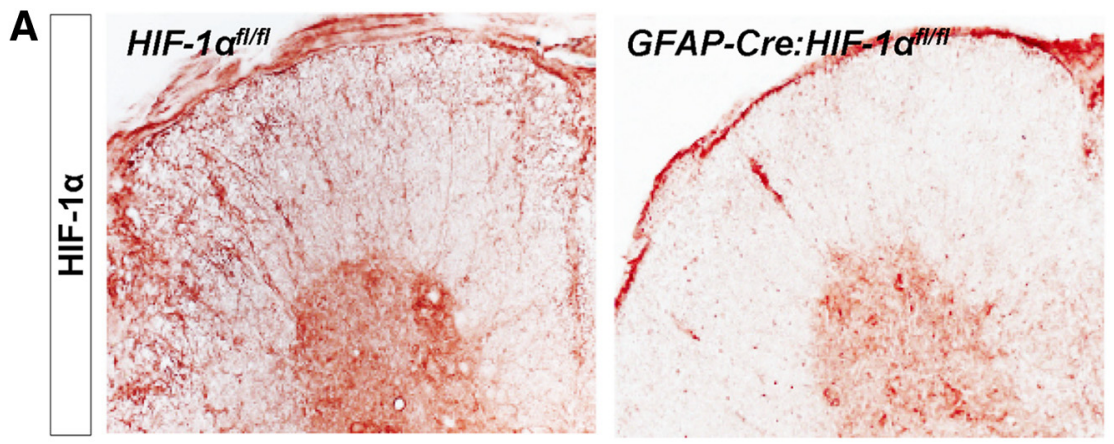

B

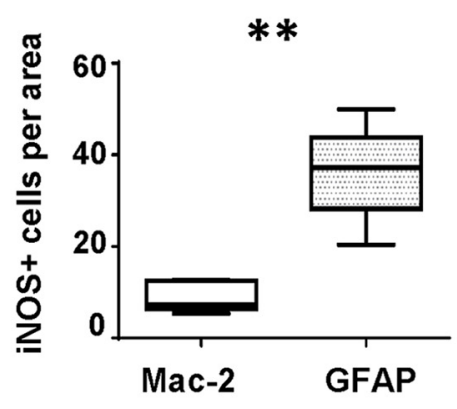

D

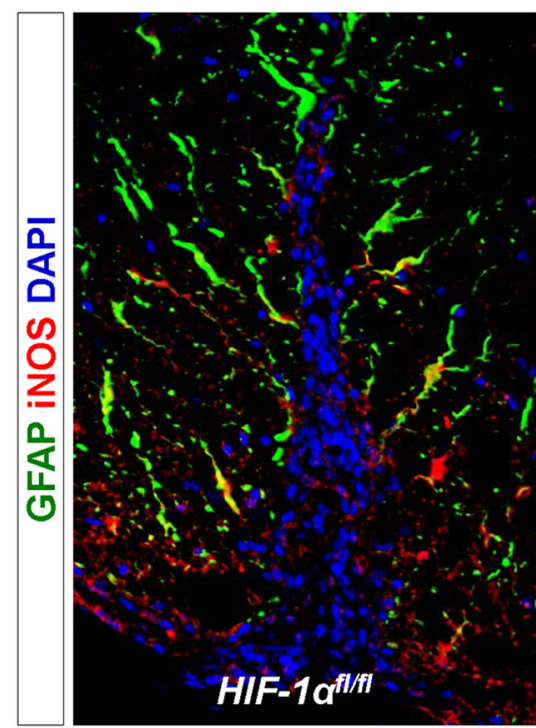

E

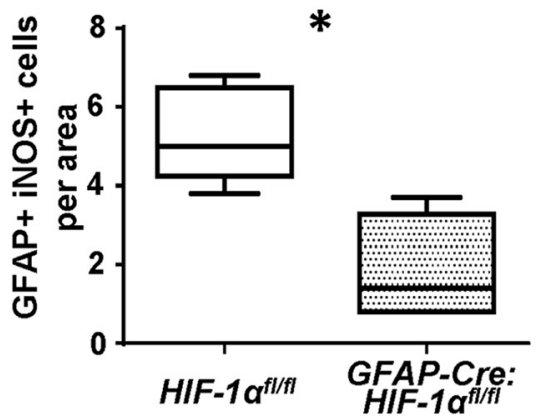

C

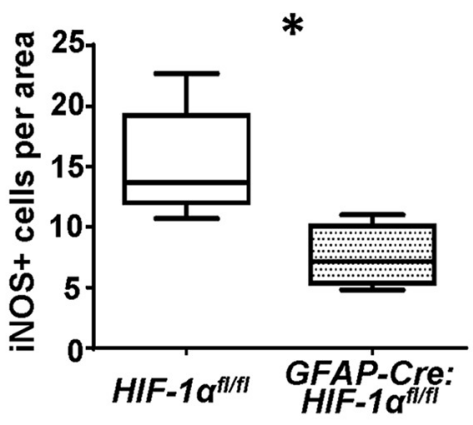

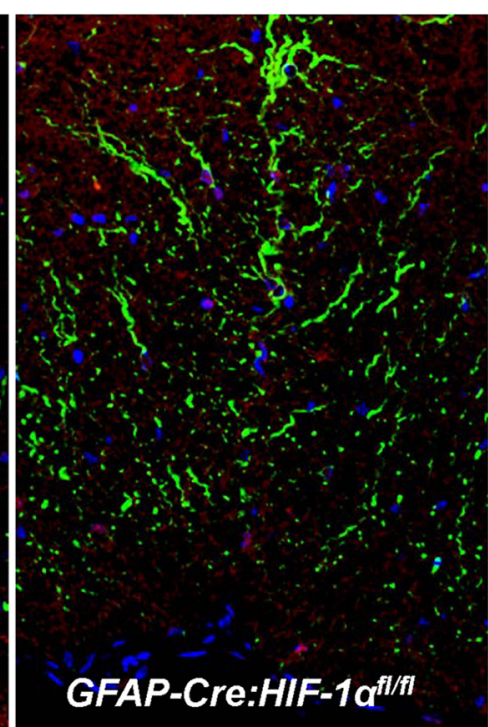

F

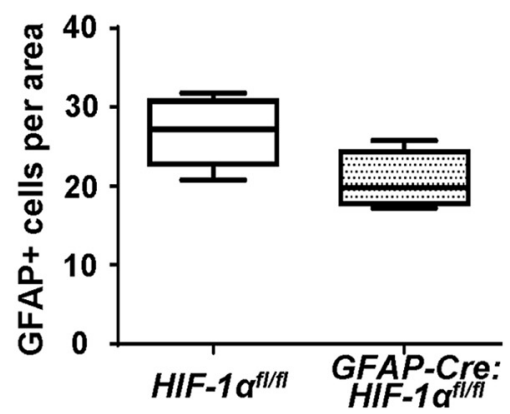

Figure 4 Genetic depletion of HIF-1 $\alpha$ in astrocytes decreases expression of HIF-1 $\alpha$ and iNOS in astrocytes. A, Staining for HIF-1 $\alpha$ in GFAP-Cre:HIF-1 $\alpha^{f / f l}$ and HIF-1 $\alpha^{f / f l}$ mice after EAE. B, Quantification of iNOS expression in Mac-2+ macrophages and GFAPexpressing astrocytes at peak EAE in $H I F-1 \alpha^{f l / f l}$ mice $(n=5)$. Area $=0.056 \mathrm{~mm}^{2}$. Data are presented as mean $\pm \mathrm{SEM}$ from $n=5 \mathrm{mice}$. Statistical analysis was performed using an unpaired $t$-test with Welch's correction $\left(p=0.003^{\circ}\right)$. C, Quantification iNOS+ cells at peak EAE in HIF-1 $\alpha^{f / f l}(n=5)$ and GFAP-Cre:HIF-1 $\alpha^{f / f l}(n=4)$ mice. Area $=0.056 \mathrm{~mm}^{2}$. Data are presented as mean \pm SEM. (continued on page 10). 
continued

Statistical analysis was performed an unpaired $t$ test $\left(p=0.034^{p}\right)$. $\boldsymbol{D}$, Double-immunofluorescence of GFAP (green) and iNOS (red) in $H I F-1 \alpha^{f l f l}$ and GFAP-Cre:HIF-1 $\alpha^{f l / f l}$ mice at peak EAE. Statistical analysis was performed using an unpaired $t$ test $\left(p=0.01^{9}\right)$. $\boldsymbol{E}$, Quantification of iNOS + GFAP+ cells reveals reduced iNOS-expressing astrocytes in GFAP-Cre:HIF-1 $\alpha^{\text {fllff }}(n=4)$ compared with $H I F-1 \alpha^{f l / f l}(n=5)$ mice. Area $=0.056 \mathrm{~mm}^{2}$. Statistical analysis was performed using an unpaired $t$ test $\left(p=0.0159^{9}\right)$. $\boldsymbol{F}$, Quantification of GFAP+ astrocytes shows similar numbers of astrocytes in GFAP-Cre:HIF- $1 \alpha^{f l / f l}(n=4)$ and $H I F-1 \alpha^{f l / f l}(n=5)$ mice at peak EAE. Area $=0.056 \mathrm{~mm}^{2}$. Data are presented as mean \pm SEM. Statistical analysis was performed using an unpaired $t$ test $(p=0.06)$. Superscript letters refer to the statistical results in Tables 1, 2, and Results.

matoid arthritis and chronic cutaneous inflammation (Cramer et al., 2003) and stroke (Baranova et al., 2007) have shown that HIF- $1 \alpha$ exerts a profound influence on disease progression. Therefore, we hypothesized that HIF-1 $\alpha$ deficiency in glial cells would likely be protective and HIF- $1 \alpha$ overexpression would exacerbate inflammation in the
EAE mouse model. However, our EAE experiments conclusively show that genetic ablation of HIF- $1 \alpha$ in astroglia and macrophages does not alter disease progression. It is possible that HIF- $1 \alpha$ deficiency or exacerbation in astrocytes did not alter EAE progression because of the additional cell sources expressing $\mathrm{HIF}-1 \alpha$, including

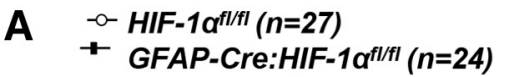

$$
\text { B } \quad \begin{aligned}
&-H I F-1 a^{f l / f l}(n=13) \\
& \quad-G F A P-C r e: I y s M-C r e: H I F-1 \alpha^{f I / f l}(n=16)
\end{aligned}
$$
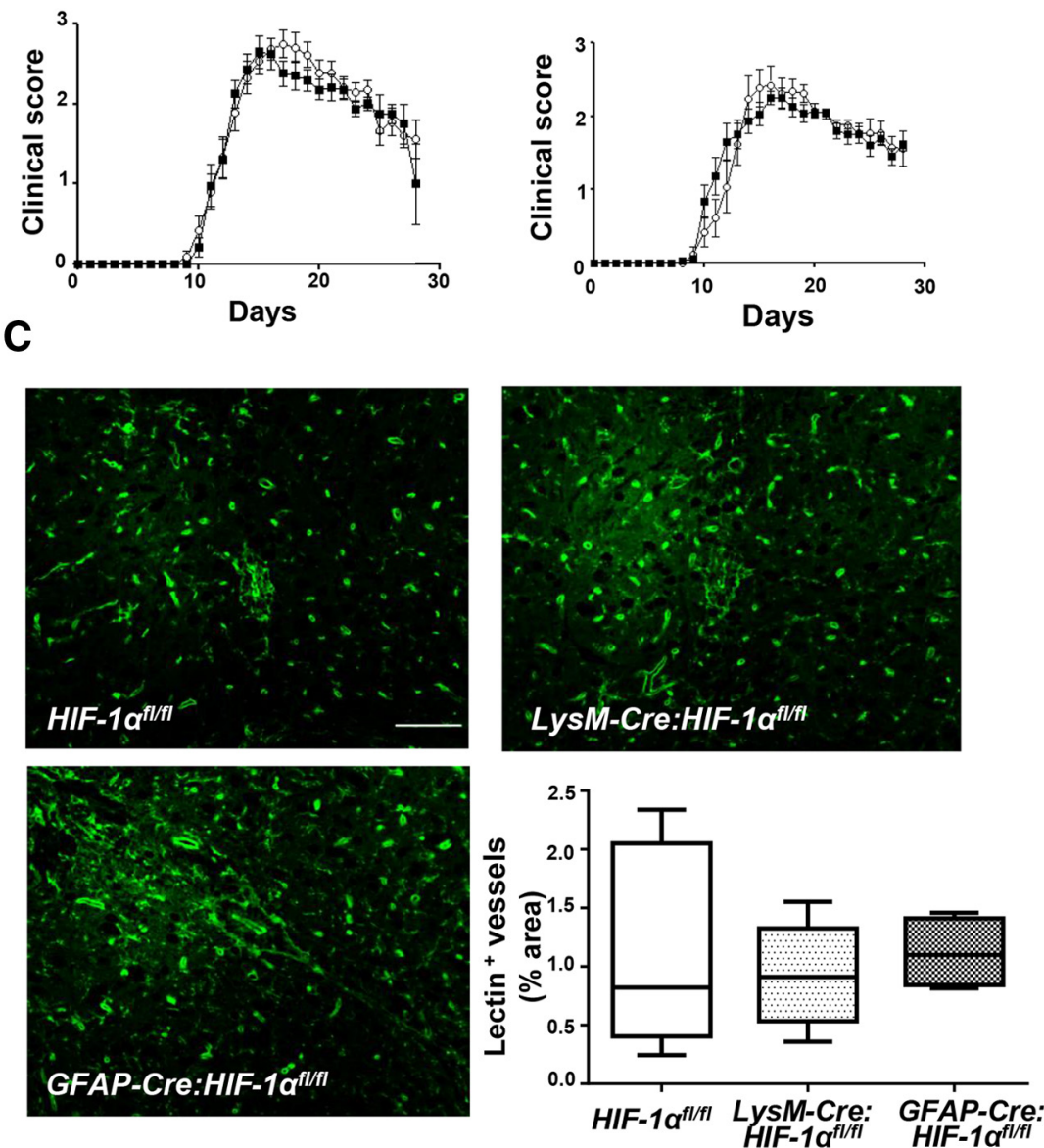

Figure 5 Genetic depletion of HIF-1 $\alpha$ in astrocytes or in both astrocytes and myeloid cells does not affect the clinical course of EAE. $\boldsymbol{A}$, Clinical scores of mice genetically depleted for HIF-1 $\alpha$ in astrocytes GFAP-Cre:HIF- $1 \alpha^{f l f f}(n=24)$ and control mice HIF-1 $\alpha^{f l / f l}(n=$ 27). $\boldsymbol{B}$, Clinical scores of mice genetically depleted for HIF-1 $\alpha$ in astrocytes and myeloid cells GFAP-Cre:lysM-Cre:HIF-1 $\alpha^{f l f l}(n=16)$ and control mice HIF-1 $\alpha^{f l f l}(n=13)$. $\boldsymbol{A}$ and $\boldsymbol{B}$, For each genotype, day of onset, maximum clinical score, and percentage of mice developing signs of paralysis were calculated using mixed linear effects models, and the results are presented in Table 1. Data are presented as mean \pm SEM. C, Immunostaining for tomato-lectin shows no significant differences in lectin+ vessels between $H I F-1 \alpha^{f l / f l}(n=5)$, IysM-Cre:HIF-1 $\alpha^{f l / f l}(n=5)$, and GFAP-Cre:HIF-1 $\alpha^{f l / f l}(n=4)$ at peak EAE. Data are expressed as percentage of lectin + area per mouse and presented as mean \pm SEM. Statistical analysis was performed using one-way ANOVA ( $\left.p=0.83^{y}\right)$. Superscript letter refers to the statistical results in Tables 1, 2, and Results. 
oligodendrocytes and T cells. Indeed, a recent study showed that mice lacking HIF- $1 \alpha$ in $\mathrm{CD}^{+} \mathrm{T}$ cells are deficient in IL-17 production and are more resistant to EAE (Dang et al., 2011). Furthermore, HIF- $1 \alpha$ signaling in oligodendrocytes is essential for postnatal myelination (Yuen et al., 2014). Depending on the cell source, HIF-1 $\alpha$ might have positive and negative effects in inflammatory demyelination. On one hand, HIF- $1 \alpha$ could exacerbate pathogenesis by increasing BBB opening and inflammatory infiltration. On the other hand, $\mathrm{HIF}-1 \alpha$ may also have protective effects on oligodendrocyte and neuronal survival. Genetic ablation of HIF-1 $\alpha$ might cancel out its diverse effects, thus preventing measurable effects in clinical signs and disease pathogenesis. Last, another possible explanation for the lack of effect of HIF- $1 \alpha$ genetic manipulation in EAE could be the partial overlapping functions between $\mathrm{HIF}-1 \alpha$ and its homolog HIF-2 $\alpha$. Although our study suggests that depletion of HIF- $1 \alpha$ in astrocytes or myeloid-lineage cells does not affect vascular density in EAE, depletion of HIF- $1 \alpha$ in oligodendrocytes regulates white matter angiogenesis (Yuen et al., 2014). Future studies are required to further characterize the effects of astrocytic and myeloid HIF- $1 \alpha$ on inflammatory infiltrate subsets by FACS and angiogenic processes, such as BBB permeability, which can influence CNS inflammation, demyelination, and axonal loss.

Although the use of the human GFAP-cre mouse line in our study might have influenced HIF- $1 \alpha$ expression in neurons and oligodendrocytes in addition to astrocytes, we did not observe effects on the course of EAE GFAPcre:HIF-1 $\alpha^{f l / f l}$ mice. Therefore, it is unlikely that potential unspecific and partial reduction of HIF- $1 \alpha$ in neurons and oligodendrocytes could have masked the effect of astrocytic HIF- $1 \alpha$ depletion. The lack of effect of HIF- $1 \alpha$ genetic manipulation in glial cells might stem from the use of the MOG-EAE model used in our study. However, because pharmacological manipulation of HIF- $1 \alpha$ influences clinical symptoms in similar models of CNS autoimmunity (Dore-Duffy et al., 2011; Huh et al., 2011), it is likely that alternate HIF- $1 \alpha$-expressing cell types might contribute to inflammatory demyelination. In contrast to the GFAP-cre mouse line that may target additional cell types, the use of lys-cre line might not fully achieve HIF- $1 \alpha$ depletion in the myeloid lineage. Therefore, future studies in recently generated microglial-specific cre mice (Parkhurst et al., 2013) could increase the HIF- $1 \alpha$ depletion and shed light in microglial-specific depletion of HIF- $1 \alpha$ in inflammatory demyelination.

Our findings that HIF- $1 \alpha$ is upregulated in astrocytes and inflammatory cells of white matter areas are in agreement with studies in MS patients. HIF- $1 \alpha$ and its downstream genes are upregulated in the brains of MS patients. We observed primarily changes in protein expression of $\mathrm{HIF-} 1 \alpha$, suggesting that post-translational modifications that stabilize HIF- $1 \alpha$ are primarily involved in $\mathrm{HIF}-1 \alpha$ upregulation in EAE. HIF- $1 \alpha$ stabilization may reflect a reactive change within cells consecutive to the hypoxic and inflammatory conditions and might play a causative role in the formation of demyelinating plaques. Indeed, we observed significant increase in HIF-1 $\alpha$ levels at the peak of EAE and did not detect $\mathrm{HIF}-1 \alpha$ upregulation at the onset of the disease. It is possible that HIF-1 $\alpha$ accumulation is either too low to be detected at early stages or occurs after the onset of EAE. Future studies using sensitive methods to detect upregulation of HIF- $1 \alpha$ at early stage in EAE would be crucial to determine its relationship with early tissue alterations.

In summary, our data demonstrate that deleting HIF- $1 \alpha$ in astrocytes and/or myeloid cells or deleting its negative regulator VHL in myeloid cells is insufficient to affect the clinical course of EAE. Further experiments targeting $\mathrm{HIF-1} \alpha$ in other glial cell types, such as oligodendrocytes or T-cell subsets, are needed to fully understand the function of $\mathrm{HIF}-1 \alpha$ in inflammatory demyelinating diseases.

\section{References}

Aboul-Enein F, Rauschka H, Kornek B, Stadelmann C, Stefferl A, Brück W, Lucchinetti C, Schmidbauer M, Jellinger K, Lassmann $\mathrm{H}$ (2003) Preferential loss of myelin-associated glycoprotein reflects hypoxia-like white matter damage in stroke and inflammatory brain diseases. J Neuropathol Exp Neurol 62:25-33. Medline

Adams RA, Bauer J, Flick MJ, Sikorski SL, Nuriel T, Lassmann H, Degen JL, Akassoglou K (2007) The fibrin-derived gamma377-395 peptide inhibits microglia activation and suppresses relapsing paralysis in central nervous system autoimmune disease. J Exp Med 204:571-582. CrossRef Medline

Argaw AT, Zhang Y, Snyder BJ, Zhao ML, Kopp N, Lee SC, Raine CS, Brosnan CF, John GR (2006) IL-1beta regulates blood- brain barrier permeability via reactivation of the hypoxia-angiogenesis program. J Immunol 177:5574-5584. CrossRef Medline

Bajenaru ML, Zhu Y, Hedrick NM, Donahoe J, Parada LF, Gutmann DH (2002) Astrocyte-specific inactivation of the neurofibromatosis 1 gene (NF1) is insufficient for astrocytoma formation. Mol Cell Biol 22:5100-5113. 10.1128/MCB.22.14.5100-5113. Medline

Baranova O, Miranda LF, Pichiule P, Dragatsis I, Johnson RS, Chavez JC (2007) Neuron-specific inactivation of the hypoxia inducible factor 1 alpha increases brain injury in a mouse model of transient focal cerebral ischemia. J Neurosci 27:6320-6332. CrossRef

Bates D, Maechler M, Bolker B (2013) Ime4: linear mixed-effects models using Eigen and S4. R package version 1.0-5.

Brück W, Stadelmann C (2005) The spectrum of multiple sclerosis: new lessons from pathology. Curr Opin Neurol 18:221-224. CrossRef Medline]

Clausen BE, Burkhardt C, Reith W, Renkawitz R, Förster I (1999) Conditional gene targeting in macrophages and granulocytes using LysMcre mice. Transgenic Res 8:265-277. CrossRef Medline

Cramer T, Yamanishi Y, Clausen BE, Förster I, Pawlinski R, Mackman $\mathrm{N}$, Haase VH, Jaenisch R, Corr M, Nizet V, Firestein GS, Gerber HP, Ferrara N, Johnson RS (2003) HIF-1alpha is essential for myeloid cell-mediated inflammation. Cell 112:645-657. CrossRef Medline

Dang EV, Barbi J, Yang HY, Jinasena D, Yu H, Zheng Y, Bordman Z, Fu J, Kim Y, Yen HR, Luo W, Zeller K, Shimoda L, Topalian SL, Semenza GL, Dang CV, Pardoll DM, Pan F (2011) Control of $T(H)$ 17/T(reg) balance by hypoxia-inducible factor 1 . Cell 146:772-784. CrossRef Medline

Dore-Duffy P, Wencel M, Katyshev V, Cleary K (2011) Chronic mild hypoxia ameliorates chronic inflammatory activity in myelin oligodendrocyte glycoprotein (MOG) peptide induced experimental autoimmune encephalomyelitis (EAE). Adv Exp Med Biol 701:165173. CrossRef Medline

Graumann U, Reynolds R, Steck AJ, Schaeren-Wiemers N (2003) Molecular changes in normal appearing white matter in multiple sclerosis are characteristic of neuroprotective mechanisms against hypoxic insult. Brain Pathol 13:554-573. Medline 
Haase VH, Glickman JN, Socolovsky M, Jaenisch R (2001) Vascular tumors in livers with targeted inactivation of the von Hippel-Lindau tumor suppressor. Proc Natl Acad Sci USA 98:1583-1588. CrossRef Medline

Huh JR, Leung MW, Huang P, Ryan DA, Krout MR, Malapaka RR, Chow J, Manel N, Ciofani M, Kim SV, Cuesta A, Santori FR, Lafaille JJ, Xu HE, Gin DY, Rastinejad F, Littman DR (2011) Digoxin and its derivatives suppress $\mathrm{TH} 17$ cell differentiation by antagonizing RORgammat activity. Nature 472:486-490. CrossRef Medline

Kaelin WG Jr (2008) The von Hippel-Lindau tumour suppressor protein: O2 sensing and cancer. Nat Rev Cancer 8:865-873. CrossRef Medline

Laird NM, Ware JH (1982) Random-effects models for longitudinal data. Biometrics 38:963-974. CrossRef Medline

Lassmann H (2003) Hypoxia-like tissue injury as a component of multiple sclerosis lesions. J Neurol Sci 206:187-191. CrossRef Medline

Le Moan N, Houslay DM, Christian F, Houslay MD, Akassoglou K (2011) Oxygen-dependent cleavage of the p75 neurotrophin receptor triggers stabilization of HIF-1alpha. Mol Cell 44:476-490. CrossRef Medline

Lee Y, Zhu B, Pulicicchio C, McMonagle-Strucko K, Wettstein JG, Cosmatos D (2003) Statistical method for analysis of the disease curve in animals with experimental autoimmune encephalomyelitis. J Biopharm Stat 13:141-158. CrossRef Medline

Majmundar AJ, Wong WJ, Simon MC (2010) Hypoxia-inducible factors and the response to hypoxic stress. Mol Cell 40:294-309. CrossRef Medline

Marik C, Felts PA, Bauer J, Lassmann H, Smith KJ (2007) Lesion genesis in a subset of patients with multiple sclerosis: a role for innate immunity? Brain 130:2800-2815. CrossRef Medline

Parkhurst CN, Yang G, Ninan I, Savas JN, Yates JR 3rd, Lafaille JJ, Hempstead BL, Littman DR, Gan WB (2013) Microglia promote learning-dependent synapse formation through brain-derived neurotrophic factor. Cell 155:1596-1609. CrossRef Medline

Peyssonnaux C, Cejudo-Martin P, Doedens A, Zinkernagel AS, Johnson RS, Nizet V (2007) Cutting edge: essential role of hypoxia inducible factor-1alpha in development of lipopolysaccharideinduced sepsis. J Immunol 178:7516-7519. CrossRef Medline

R Core Team (2013) R: a language and environment for statistical computing. Vienna: R Foundation for Statistical Computing.
Ryan HE, Poloni M, McNulty W, Elson D, Gassmann M, Arbeit JM, Johnson RS (2000) Hypoxia-inducible factor-1alpha is a positive factor in solid tumor growth. Cancer Res 60:4010-4015. Medline

Safran M, Kim WY, O'Connell F, Flippin L, Günzler V, Horner JW, Depinho RA, Kaelin WG Jr (2006) Mouse model for noninvasive imaging of HIF prolyl hydroxylase activity: assessment of an oral agent that stimulates erythropoietin production. Proc Natl Acad Sci USA 103:105-110. CrossRef Medline

Sharp FR, Bernaudin M (2004) HIF1 and oxygen sensing in the brain. Nat Rev Neurosci 5:437-448. CrossRef Medline

Stadelmann C, Ludwin S, Tabira T, Guseo A, Lucchinetti CF, LeelOssy L, Ordinario AT, Brück W, Lassmann H (2005) Tissue preconditioning may explain concentric lesions in Balo's type of multiple sclerosis. Brain 128:979-987. CrossRef Medline

Sun L, Marti HH, Veltkamp R (2008) Hyperbaric oxygen reduces tissue hypoxia and hypoxia-inducible factor-1 alpha expression in focal cerebral ischemia. Stroke 39:1000-1006. CrossRef Medline

Thiel M, Caldwell CC, Kreth S, Kuboki S, Chen P, Smith P, Ohta A Lentsch AB, Lukashev D, Sitkovsky MV (2007) Targeted deletion of HIF-1alpha gene in T cells prevents their inhibition in hypoxic inflamed tissues and improves septic mice survival. PLoS One 2:e853. CrossRef

Vangeison G, Carr D, Federoff HJ, Rempe DA (2008) The good, the bad, and the cell type-specific roles of hypoxia inducible factor-1 alpha in neurons and astrocytes. J Neurosci 28:1988-1993. CrossRef Medline

Weidemann A, Kerdiles YM, Knaup KX, Rafie CA, Boutin AT, Stockmann C, Takeda N, Scadeng M, Shih AY, Haase VH, Simon MC, Kleinfeld D, Johnson RS (2009) The glial cell response is an essential component of hypoxia-induced erythropoiesis in mice. $J$ Clin Invest 119:3373-3383. CrossRef Medline

Yuen TJ, Silbereis JC, Griveau A, Chang SM, Daneman R, Fancy SP, Zahed H, Maltepe E, Rowitch DH (2014) Oligodendrocyteencoded HIF function couples postnatal myelination and white matter angiogenesis. Cell 158:383-396. CrossRef Medline

Zeis T, Graumann U, Reynolds R, Schaeren-Wiemers N (2008) Normal-appearing white matter in multiple sclerosis is in a subtle balance between inflammation and neuroprotection. Brain 131: 288-303. CrossRef

Zinkernagel AS, Johnson RS, Nizet V (2007) Hypoxia inducible factor (HIF) function in innate immunity and infection. J Mol Med 85: 1339-1346. CrossRef Medline 